\title{
High-resolution paleoenvironmental studies: an editorial note *
}

\author{
André F. Lotter ${ }^{1,2}$ \& Michael Sturm ${ }^{1}$ \\ ${ }^{1}$ Swiss Federal Institute for Environmental Science and Technology, (EAWAG), CH-8600 Dübendorf, Switzerland \\ ${ }^{2}$ Geobotanik, Universitut Bern, Altenbergrain 21, CH-3013 Bern, Switzerland
}

Received 20 July 1994; accepted 21 July 1994

The papers presented in this special issue of the Journal of Paleolimnology were part of a special session on 'High Resolution Records' of the 6th International Paleolimnology Symposium, held between 1921 April 1993 at the Australian National University in Canberra, Australia. The interdisciplinary nature of paleolimnology brings together scientists from a wide range of subjects such as limnology, biology, geology, physics, chemistry, etc., and this is well reflected in the contributions presented in this special issue.

Due to the lack of instrumental time-series extending over more than the last 50-100 years, paleoenvironmental studies employing different proxy-data archives such as sediments, tree-rings, ice-cores and historical records have become an important tool in understanding past changes and natural variability in environmental systems (Eddy, 1992). They thus are comparable to long-term monitoring studies (see, e.g., Jacobson, 1988). The higher the resolution of such studies, the better the proxy-data generated can be related to modern instrumental data. As such highresolution paleo-studies are very labour-intensive, they are usually only carried out for specific time-windows containing significant changes in biological or geochemical parameters of interest.

As the formation of environmental proxy-archives is influenced by various different environmental parameters, each archive incorporates a particular aspect of environmental history with its own inherent problems of resolution. Ice cores contain information primarily about atmospheric processes (e.g. cli-

- This is the introduction to a series of papers published in the issue on high-resolution paleolimnology. These papers were presented at the Sixth International Paleolimnology Symposium held 19-21 April, 1993 at the Australian National University, Canberra, Australia. Dr A. F. Lotter and Dr. M. Sturm served as guest editors for these papers. mate), whereas the development of tree-rings depends not only on atmospheric processes but also on local habitat factors. The formation of sediments is controlled mainly by atmospheric processes, as well as the geology of the hydrological catchment (see, e.g., Birks \& Birks, 1980). These two factors may, in turn, also control the development of different parameters and groups of organisms within the catchment (e.g. pedogenesis, vegetation) and in the lake (e.g. water chemistry, algae, zooplankton). Therefore, there is no straightforward answer to the question 'What are highresolution records?' As paleolimnology deals mainly with wet environments, we shall concentrate our discussion on sedimentary records, specifically on those from lakes.

From a methodological point of view a high analytical resolution might be considered. This is a field where very much depends on the state of the art of analytical methods. The taxonomic resolution (i.e. the taxonomic precision) in investigations of different biological organisms has reached saturation in many fields. Studies of lacustrine records, including multiple proxy indicators, have become very important lately because of the possibility of them providing several independent lines of evidence for a common phenomenon (see, e.g. PALE Steering Committee 1994).

There are different spatial and temporal scales that are important for the paleoecological and paleolimnological study of past environments (see, e.g., Birks 1986). High-resolution sampling in association with lake sediments can imply high spatial resolution, e.g., many surficial samples from the same basin or from a whole geographical region. This approach may be applied in mapping and calibration studies, where modern surface sediments provide the basis for understanding the present-day relationship of an organism 
(e.g. pollen, diatoms, chironomids) to a parameter of interest (e.g. climate, lake pH; see, e.g., COHMAP Members 1988,. Smol et al., 1986; Battarbee et al., 1990; Walker et al., 1991).

However, the term 'high-resolution' as used in the context of the Paleolimnology Symposium session as well as in the papers presented in this special issue, is linked mainly to studies with high temporal resolution within a specific time-window. In lake sediments, temporal resolution is a function of sampling resolution, which in turn is strongly dependent on sediment accumulation rates. This fact has some important practical consequences, as the higher the accumulation rate, the higher will be the maximum possible temporal resolution in a paleolimnological investigation. Chronology is another major issue which must be taken account of if a reasonably high degree of temporal resolution is to be attained. This is best achieved either by employing physical dating methods (e.g. ${ }^{14} \mathrm{C}$, ${ }^{210} \mathrm{~Pb},{ }^{137} \mathrm{Cs}$ ) or by counting discrete annual sediment layers, i.e. varves. Paleolimnological studies involving varves allow the highest possible temporal resolution (Bradbury \& Dean, 1993; for reviews see, e.g., O'Sullivan, 1983, Saarnisto, 1986), i.e., single years or even seasons (see, e.g., Peglar 1993). Such studies may eventually result in estimates of rates of change with a temporal resolution high enough to allow comparison with modern ecological processes (see Lotter et al., 1992).

\section{References}

Battarbee, R. W., J. Mason, I. Renberg \& J. F. Talling, 1990. Palaeolimnology and lake acidification. The Royal Society, London. 445 pp.
Birks, H. J. B., 1986. Late-Quaternary biotic changes in terrestrial and lacustrine environments, with particular reference to northwest Europe. In: Berglund, B. E. (ed.), Handbook of Holocene Palaeoecology and Palaeohydrology. J. Wiley \& Sons, Chichester. 3-65.

Birks, H. J. B. \& H. H. Birks, 1980. Quaternary Palaeoecology. E. Amold, London.

Bradbury, J. P. \& W. E. Dean, 1993. Elk Lake, Minnesota: evidence for rapid climate change in the north-central United States. Geol. Soc. America Spec. Paper 276. 336 pp.

COHMAPMembers 1988. Climatic changes of the last 18000 years: observations and model simulations. Science 241: 1043-1052.

Eddy, J. A., 1992. The PAGES (Past Global Changes) Project: proposed implementation plans for research activities. IGBP Global Change Report 19. 110 pp.

Jacobson, G. L., 1988. Ancient permanent plots: sampling in paleovegetational studies. In: Huntley, B. \& Webb, T. (eds.), Vegetation History. 3-16.

Lotter, A. F., B. Ammann \& M. Sturm, 1992. Rates of change and chronological problems during the late-glacial period. Climate Dynamics 6: 233-239.

PALE Steering Committee 1994. Research protocols for PALE Paleoclimate of Arctic Lakes and Estuaries. PAGES Workshop Report Series 94-1: 1-53.

Peglar, S. M., 1993. The mid-Holocene Ulmus decline at Diss Mere, Norfolk, U.K.: a year-by-year pollen stratigraphy from annual laminations. The Holocene 3: 1-13.

O'Sullivan, P. E., 1983. Annually-laminated lake sediments and the study of quatemary environmental changes - a review. Quat. Sci. Revue 1: 245-313.

Saarnisto, M., 1986. Annually laminated lake sediments. In: Berglund, B. E. (ed.), Handbook of Holocene Palaeoec-1ogy and Palaeohydrology. J. Wiley \& Sons, Chichester: 343-37U.

Smol, J. P., R. W. Battarbee, R. B. Davis \& J. Merilainen, 1986. Diatoms and lake acidity. Junk, Dordrecht, 307 pp.

Walker, I. R., J. P. Smol, D. R. Engstrom \& H. J. B. Birks, 1991. An assessment of Chironomidae as aquatic indicators of climatic change. Can. J. Fish. aquat. Sci. 48: 975-987. 